\title{
Mucocutaneous Manifestations in HIV/AIDS Patients
}

\author{
Afif Nurul Hidayati ${ }^{1}$, Citra Dwi Harningtyas ${ }^{1}$, Damayanti ${ }^{1}$, Maylita Sari ${ }^{1}$, Linda \\ Astari $^{1}$, Diah Mira Indramaya ${ }^{1}$, M. Yulianto Listiawan', Budi Utomo², Budiono ${ }^{2}$, Dwi \\ Murtiastutik $^{1}$, Septiana Widyantari ${ }^{1}$, Astindari ${ }^{1}$ \\ ${ }^{1}$ Department of Dermatology and Venereology, Faculty of Medicine, Universitas Airlangga/ Dr. \\ Soetomo General Academic Hospital, Universitas Airlangga Teaching Hospital, Surabaya \\ ${ }^{2}$ Department of Public Health Sciences, Faculty of Medicine, Universitas Airlangga, Surabaya
}

\begin{abstract}
Background: The main target of human immunodeficiency virus (HIV) is cluster of differentiation 4 (CD4) T lymphocytes and several other immune cells that have CD4 receptors. They are also present in skin and mucosa, such as Langerhans cells (LC). Mucocutaneous lesions are one of the first clinical presentations of immunosuppression in HIV seropositive patients that manifest at different stages of the infection and require early diagnosis and prompt treatment. Purpose: To determine the clinical characteristics and the pattern of various mucocutaneous manifestations in Human immunodeficiency virus/Acquired immune deficiency syndrome (HIV/AIDS) patients at Intermediate Care and Infectious Diseases Dr. Soetomo General Academic Hospital Surabaya. Methods: This is a descriptive retrospective study with a cross-sectional design. The study subject was classified as all HIV-AIDS patients with mucocutaneous manifestations treated in Intermediate Care and Infectious Diseases Dr. Soetomo General Academic Hospital Surabaya in 2019. Result: Out of the 614 patients who participated in the study, $72.1 \%$ were males. The majority of patients were in the age group $25-49$ years $(75.4 \%)$. The most common risk factor was heterosexuality (41.7\%). Based on the distribution of mucocutaneous manifestations, the most common mucocutaneous manifestation was candidiasis mucocutan 387 patients (49.4\%) followed by the pruritic papular eruption (PPE) 118 patients $(15.1 \%)$ and human papillomavirus infection 57 patients $(7.3 \%)$. Conclusion: Mucocutaneous manifestations occur throughout the course of HIV infection, and they can be considered as good clinical indicators for the progression of the disease and underlying immune status in resource-poor settings.
\end{abstract}

Keywords: mucocutaneous, CD4, immune status, AIDS/HIV/Human immunodeficiency.

Correspondence address: Afif Nurul Hidayati, Department of Dermatology and Venerology, Faculty of Medicine, Universitas Airlangga/ Dr. Soetomo General Academic Hospital/ Universitas Airlangga Teaching Hospital, Surabaya, Jl. Mayjen Prof. Dr. Moestopo No. 6-8 Surabaya 60131, Indonesia. Phone: (031) 5501609, e-mail: afif_nurulhidayati@fk.unair.ac.id.

Article info | Submited: 30-8-2021, Accepted: 22-9-2021, Published: 30-11-2021

\section{BACKGROUND}

Human immunodeficiency virus (HIV) is a retrovirus that attacks and destroys cluster of differentiation 4 (CD4) $\mathrm{T}$ lymphocytes and other immune cells with CD4 receptors. ${ }^{1,2}$ Acquired immunodeficiency syndrome (AIDS) is a collection of symptoms or diseases caused by decreased body immunity due to infection by HIV virus and is the final stage of HIV infection. ${ }^{3}$ Although it tends to fluctuate, data on HIV/AIDS cases in Indonesia continues to increase from year to year. In the last eleven years, the number of HIV cases in Indonesia reached its peak in 2019, which was 50,282 cases. In 2019, World Health Organization (WHO) reported 78\% new HIV/AIDS infections in the Asia Pacific region. ${ }^{4}$

The main target of HIV is a subset of lymphocytes originating from the thymus, namely helper $\mathrm{T}$ cells, causing a deficiency of cellular immunity, which is deficient in T helper lymphocytes (CD4 + cells). They are also present in skin tissue, such as Langerhans cells (LC). Langerhans cells are a specific subset of dendritic cells (DC) and are antigen presenting cells. Langerhans cell is located within the epithelium of the skin and mucosa. ${ }^{5,6}$ Changes in patient's status and low CD4 cell counts are associated with an increased frequency of mucocutaneous manifestations. Mucocutaneous manifestations are found in $80 \%-95 \%$ of HIV-infected patients. $^{3}$ It is almost certain that HIV-infected individuals will develop skin-related disorders sometime during HIV disease. The spectrum and frequency of mucocutaneous manifestations may vary in different regions and different populations. ${ }^{5}$

This retrospective study aims to determine the clinical characteristics and pattern of various mucocutaneous manifestations in HIV/AIDS patients at Intermediate Care and Infectious Diseases Dr. Soetomo General Academic Hospital Surabaya in 2019 with secondary data from medical records. 


\section{METHODS}

This descriptive retrospective study with a crosssectional design aims to determine clinical characteristics and mucocutaneous manifestations in HIV/AIDS patients at Intermediate Care and Infectious Diseases Dr. Soetomo General Academic Hospital in 2019. This unit is a special treatment room for people living with HIV (PLHIV) in Surabaya, Indonesia.

The study subject was all patients diagnosed with HIV/AIDS with mucocutaneous manifestations, which were treated in Intermediate Care and Infectious Diseases Dr. Soetomo General Academic Hospital Surabaya in 2019. The descriptive data included the clinical characteristics of gender, age, risk factor, and mucocutaneous manifestation.

This research has been through the Ethics Committee review in Dr. Soetomo General Academic Hospital Surabaya with reference number:
0032/LOE/301.4.2/VI/2020.

\section{RESULT}

Out of the 614 patients who participated in the study, 443 (72.1\%) were males, and 171 (27.9\%) were females. The male to female ratio was $2.59: 1$. The mean age upon presentation was $37 \pm 10.87$ years. The youngest patient was 1 year old, and the oldest was 92 years old. Most cases of HIV/AIDS with mucocutaneous manifestations were found in the age group of 25-49 years, as many as 463 patients $(75.4 \%)$. Distribution of risk factors most of them were heterosexual as many as 256 patients $(41.7 \%)$, homosexual 59 patients $(9.6 \%)$, bisexual 5 patient $(0.8 \%)$, maternal 4 patients $(0.7 \%)$, and injecting drug user 1 patient $(0.2 \%)$. There were 289 patients whose risk factors were unknown or as much as $47.1 \%$ (Table $1)$.

Table 1. Clinical characteristics of sex, age, and risk factor on HIV and AIDS patients with mucocutaneous manifestations

\begin{tabular}{lr}
\hline Characteristics & $\begin{array}{r}\text { Total } \\
\mathrm{n}(\%)\end{array}$ \\
\hline Sex & \\
Male & $443(72.1)$ \\
Female & $171(27.9)$ \\
Age (years old) & \\
$<4$ & $2(0.3)$ \\
$5-14$ & $2(0.3)$ \\
$15-19$ & $2(0.3)$ \\
$20-24$ & $58(9.4)$ \\
$25-49$ & $463(75.4)$ \\
$>50$ & $87(14.2)$ \\
Risk Factor & \\
Heterosexsual & $256(41.7)$ \\
Homosexsual & $59(9.6)$ \\
Bisexsual & $5(0.8)$ \\
Injecting Drug User (IDU) & $1(0.2)$ \\
Maternal & $4(0.7)$ \\
No Data & $289(47.1)$ \\
\hline
\end{tabular}

There are 3 groups of mucocutaneous manifestations consisting of infectious, non-infectious, and malignancy. There are 13 types of diseases, pyoderma infection, syphilis, human papillomavirus infection (condyloma and verruca), herpes simplex (herpes labialis, genital herpes), herpes zoster, molluscum contagiosum, candidiasis, dermatophytosis, seborrheic dermatosis, psoriasis, pruritic papular eruptions, xerosis, and drug eruptions found on this study (Table 2). The group with the most mucocutaneous manifestations was infection with 525 cases $(67.0 \%)$, the second was the inflammatory or non-infectious group with 256 cases $(32.7 \%)$, and the third was malignancy with 2 cases $(0.3 \%)$. The most common infection found in this study was fungal infection with $49.4 \%$, as mucocutaneous candidiasis. The most non-infectious cases were pruritic papular eruptions (15.1\%). In this study, 2 cases of malignancy were found in the form of lymphoma $(0.4 \%)$. 
Table 2. Distribution of mucocutaneous manifestations in HIV/AIDS patients

\begin{tabular}{|c|c|c|}
\hline $\begin{array}{l}\text { Category of Mucocutan } \\
\text { manifestation }\end{array}$ & Diseases & $\begin{array}{l}\text { Total } \\
\mathrm{n}(\%)\end{array}$ \\
\hline Infection & & $525(67.0)$ \\
\hline \multirow[t]{8}{*}{ Bacterial } & Pyoderma & $29(3.7)$ \\
\hline & - Furuncles & 5 \\
\hline & - Carbuncle & 4 \\
\hline & - Secondary infection & 20 \\
\hline & Syphilis & $28(3.6)$ \\
\hline & - Primary & 4 \\
\hline & - Secondary & 14 \\
\hline & - Latency & 10 \\
\hline \multirow[t]{11}{*}{ Fungal } & Mucocutaneous candidiasis & $387(49.4)$ \\
\hline & - Cutaneous candidiasis & 1 \\
\hline & - Oris candidiasis & 383 \\
\hline & - Vulvovaginal candidiasis & 3 \\
\hline & Dermatophytosis & $20(2.6)$ \\
\hline & - Tinea corporis & 14 \\
\hline & - Tinea pedis & 2 \\
\hline & - Tinea barbae & 1 \\
\hline & - Tinea cruris & 1 \\
\hline & - Tinea manum & 1 \\
\hline & - Tinea capitis & 1 \\
\hline \multirow[t]{8}{*}{ Virus } & Human papillomavirus infection & $57(7.3)$ \\
\hline & - Condyloma Akuminata & 54 \\
\hline & - Verruca & 3 \\
\hline & Herpes simplex virus infection & $4(0.5)$ \\
\hline & - Herpes Labialis & 1 \\
\hline & - Herpes Genitalis & 3 \\
\hline & Herpes Zooster & $16(2)$ \\
\hline & Molluscum contagiosum & $4(0.5)$ \\
\hline \multirow[t]{11}{*}{ Non-infection } & & $256(32.7)$ \\
\hline & Seborrheic Dermatosis & $37(4.7)$ \\
\hline & Psoriasis & $2(0.3)$ \\
\hline & Pruritic Papular Eruption (PPE) & $118(15.1)$ \\
\hline & Xerosis & $47(6.0)$ \\
\hline & Drug reaction & $32(4.1)$ \\
\hline & - Steven Johnson Syndrome & 4 \\
\hline & - Exanthem morbiliformis & 1 \\
\hline & - Drug Eruption & 25 \\
\hline & - Urtikaria & 1 \\
\hline & - Erythema multiforme & 1 \\
\hline \multirow[t]{2}{*}{ Malignancy } & & $2(0.3)$ \\
\hline & Lymphoma & $2(0.3)$ \\
\hline
\end{tabular}

* One patient may have more than one mucocutaneous manifestation

\section{DISCUSSION}

A broad spectrum of mucocutaneous manifestations during HIV illness includes infectious, non-infectious, and malignancy etiologies. Clinicians must be aware of the most common skin infections presented in HIV/AIDS patients in their respective fields, as this can aid in selecting the most appropriate empirical treatment. The epidemiological data of the present study showed that males were predominantly affected. This was comparable with data from the Directorate General of disease and prevention control sourced from the HIV, AIDS, and Sexual Transmitted infection (STI) Information System (SIHA) in 2019. The fourth-quarter report showed higher HIV and AIDS cases in males than females. In 2019, 64.50\% of HIV patients and $68.60 \%$ of AIDS patients were males. 
This is in line with the sex distribution of HIV case report from 2008 to 2019 . This is probably due to the increasing number of men sex with men (MSM) practices, unsafe sex, and intravenous drugs (IVDU), which men dominate. ${ }^{4,7}$ The most common age group in our study was 25-49 years (according to the Ministry of Health age group). This was similar to the data collected by SIHA in 2010-2019, reporting that the age group of 25-49 years or productive age had the highest number of HIV infection patients each year, with the range of $69.3 \%-73.7 \%{ }^{4}$

Human immunodeficiency virus/Acquired immune deficiency syndrome (HIV/AIDS) is spread through sexual contact with an infected person, contact or transfusion with infected blood, mother to child, and sharing contaminated needles. The most frequent transmission mode in this study was heterosexual (41.7\%), followed by homosexual (9.6\%). Kamat et al. also reported that heterosexuality is the most common mode of transmission, as much as $67.7 \%{ }^{8}$ In fact, the heterosexual route continues to be the most common route of transmission reported worldwide. ${ }^{9}$ According to data from SIHA, the proportion of AIDS cases reported according to risk factors also found that the most significant AIDS risk factors were heterosexual $(70 \%)$ and homosexual $(22 \%) .{ }^{4}$ In the mid-1990s, IVDU was the highest risk factor for HIV/AIDS transmission in Indonesia. The shift in risk factors for unsafe sex began with the increasing prevalence of sex workers from 1995-1996, followed by increased cases among MSM and housewives. ${ }^{10}$ Sex education and safe practices should be introduced early-lack of awareness of unsafe sex risks roots in the lack of health counseling for youths. More teenagers run away from home and such a situation has put them at risk of alcohol and drugs abuse, thereby increasing the risk of HIV/AIDS transmission. Alcohol and drug use can promote unsafe sex. There were $27.5 \%$ of the patients presented with no data on their risk factors as they might be reluctant to disclose detailed information due to social and cultural differences in our region. ${ }^{10,11}$

Skin disorders occur in almost every patient during the course of HIV/AIDS disease, either as a result of acquired immunodeficiency or as a result of therapy. The spectrum of skin manifestations in HIV/AIDS disease is broad and varied. ${ }^{1}$ Mucocutaneous manifestation in HIV/AIDS cases can be found in the form of infection, non-infection, and tumors. In developed countries, non-infectious cases are more common in HIV/AIDS patients. ${ }^{12}$ In this study, among the $614 \mathrm{HIV} / \mathrm{AIDS}$ infected patient with mucocutaneous manifestations, infections were the most common category observed, followed by the inflammatory or non-infection group. Mucocutaneous manifestations in HIV/AIDS patients in Indonesia may be different from those in other countries. Differences in skin pigmentation, climate, hygiene, genetics, environment, demographics, and behavioral patterns cause clinical manifestations and epidemiological patterns. ${ }^{10,14}$

In our study, fungal infections were the most common among the infectious diseases. Consistent with another study from Malaysia, the most common skin infection in this study was also fungal infection. ${ }^{13}$ Mucocutaneous candidiasis (49.4\%) was the most frequent fungal infection. This was similar to the findings of Azfar et al. and Pudjiati et al ${ }^{5,10}$ This can be due to Indonesia's tropical climate with relatively high humidity levels making various types of germs, including fungal infections, easy to grow. ${ }^{10}$

Among bacterial infections, the most common infection in our study was pyoderma $(3.7 \%)$ followed by syphilis (3.6\%). This was similar to a previous study conducted by Khat et al. in India. ${ }^{9}$ Concerning bacterial Sexual Transmitted Disease (STD), 28 cases of syphilis were reported in our study; most of them presented as secondary syphilis. Moreover, the incidence of syphilis seems to be increasing among HIV/AIDS patients compared to other STDs. No other bacterial STDs were observed. The coexistence of syphilis and HIV/AIDS noted in our study population was slightly lower than the findings of Kar et al. and Bhushanam et al. ${ }^{14}$ The lower percentage of HIV/AIDS positives with syphilis noted in our study could be attributed to the decline in the incidence of syphilis with the widespread use of penicillins for many common ailments and can be attributed to the indigenous use of antibiotics among the general population. ${ }^{9,14}$

The most common viral infection was human papillomavirus (HPV) infection (7.3\%). Sexually transmitted infections are one of the important manifestations of HIV/AIDS. ${ }^{15}$ Human papillomavirus infections in our study caused condyloma accuminata in 54 patients and verruca vulgaris in 3 patients. The incidence of genital warts in various studies involving male patients ranged from $13.8 \%$ to $21.4 \% .{ }^{16}$ Another study showed that the prevalence of condyloma acuminata in HIV/AIDS ranges from $8.8 \%$ to $53 \% .^{15}$ The fact that our patients were well-educated on barrier contraceptive measures and receiving positive prevention at our Antiretroviral Treatment (ART) center could have contributed to the lower rates of STI in our study. ${ }^{15}$ The lower incidence in our study may be also due to reduced prevalence of homosexuality in our country. ${ }^{16}$

Herpes zoster was seen in $2 \%$ of our cases. It occurs more frequently in older people and those with cellular immunodeficiency. In PLHIV, a prevalence of 
$8 \%$ has been found in other study. ${ }^{15}$ The prevalence of Molluscum contagiosum was seen $0.5 \%$ in our study, and it is lower than prevalence in other study by Abhihandan et al. $(6 \%) .{ }^{16}$ The lower frequency of herpes zoster in our study could again be attributed to early ART in our study population.

Evidence indicates that Herpes simplex virus (HSV) -HIV-1 interactions can affect the outcome of HIV-1 infection and AIDS progression in HIV-infected patients, and control of HSV infection may decelerate HIV infection. ${ }^{9}$ Herpes simplex was seen in $0.5 \%$, there were 3 patients with herpes genitalis and 1 patient with herpes labialis in our study. Herpes genitalis is reported to be the most common cause of genital ulcers among both immunocompetent and immunosuppressed individuals. Human immunodeficiency virus and HSV acts as a co-transmitter of each other. ${ }^{9,16}$

The most non-infectious cases in this study were pruritic papular eruptions, as observed in 118 patients (15.1\%). This finding is greater compared to the results of reasearch by Abhinandan et al. who also showed that pruritic papular eruptions were the most common noninfectious manifestation $(13 \%) .{ }^{15}$ Pruritic papular eruptions (PPE) constitutes the majority of cases in inflammatory or non-infectious dermatoses. PPE may appear as an early skin disease with a high CD4 cell count and is described as a stage II disease by WHO. ${ }^{10}$ A study conducted in Thailand, Wichai et al. found that PPE as the most common skin finding. Another study in Iran reported an incidence of $36.7 \% .{ }^{17}$ PPE usually appear as papules and plaques that are usually widespread, skincolored to erythematous, and usually bearing signs of excoriations. Their presence after at least 6 months of ART has been proposed as one of the several markers of treatment failure. ${ }^{15}$

Xerosis was seen in $6 \%$ of our cases. The prevalence of xerosis in HIV/AIDS varies from $2.8 \%$ to $73.3 \%$. It is one of the most common skin manifestations in HIV/AIDS and a common cause of pruritus in HIV/AIDS patients. Impaired water metabolism in the viable epidermis and reduced dermal lipids are responsible for HIV/AIDS-associated xerosis. $^{15}$

Seborrheic dermatitis is a manifestation of stage $2 \mathrm{HIV}$ and it accounts for a $1-10 \%$ prevalence in the general adult population. ${ }^{15}$ Seborrheic dermatitis was present in $4.7 \%$ of our cases, which is a smaller percentage than that reached by other studies (up to $11.9 \%$ ). Several studies have reported widespread atypical seborrheic dermatitis in patients, ranging from $15.62 \%$ to $83 \%$. The cause of seborrheic dermatitis is unknown, but many researchers believe that changes in the immune system in HIV/AIDS, altering the skin's response to the fungus, Malassezia species lead to higher infection rates. ${ }^{15,16}$ Human immunodeficiency virus/Acquired immune deficiency virus (HIV/AIDS) patients experience immunologic dysfunction, together with diversification of therapeutic drugs, the incidence of drug eruptions among these patients is usually higher than that of the general population. In our study, drug eruption was found in $4.1 \%$ of patients, this result is lower than reported in the literature. ${ }^{17}$ Drug reactions include maculopapular, urticarial rash, and StevensJohnson syndrome. The main causative agent noted was Nevirapine. ${ }^{1,19}$ The lower incidence in our study can be explained by the fact that apart from ART, relatively few drugs are used to treat minor infections because ART itself improves the general condition of the patients. It has been shown that patients with CD4+ cell counts, which is $<200$ are more likely to have a drug eruption associated with the immune function status. Therefore, patients should be able to evaluate the risk when using different hypersensitivity drugs. ${ }^{17}$

Malignancy often occurs in HIV infection and in some cases, it indicates the presence of HIV infection. ${ }^{13}$ HIV/AIDS patients are at high risk for malignancies, such as Kaposi's sarcoma, nonHodgkin's lymphoma, and cervical carcinoma. These three malignancies are often referred to as "AIDSdefining conditions", if one of the three malignancies is found, it can indicate the course of HIV infection has reached the AIDS stage. The relationship between HIV infection and certain types of malignancies is still unexplained, possibly related to a decrease in the immune system. ${ }^{10}$ In this study, only two cases of lymphoma were found, this could be due to other malignancies in patients at Dr. Soetomo General Academic Hospital who were not screened for HIV/AIDS.

The present study demonstrated that mucocutaneous manifestations are common in HIVpositive patients, some of which could be applicable as uceful clinical indicators to predict the immune status of the patients therefore, regular skin examinations are recommended as routine HIV-infected patients healthcare programs. Thus, patients with such skin complaints may be motivated to report for voluntary counseling and treatment. This points toward the changing mucocutaneous manifestations in HIV/AIDS in a post "treat all patients" scenario. Furthermore, this emphasizes the importance of health and sex education with proper models explaining the transmission of HIV/AIDS in lower socio-economic strata for prevention. The lower frequency of mucocutaneous manifestations in our study compared to the known manifestations of HIV/AIDS can be attributed to a smaller number of HIV/AIDS cases in our study, which was one of its limitations. However, further studies 
with large numbers of HIV/AIDS patients and their correlation with staging and the CD4 count will be required in the future to prove these important observations.

\section{REFERENCES:}

1. Lipworth AD, Freeman E, Saavedra AP. Cutaneous Manifestations of HIV and Human TLymphotropic Virus. In: Kang S, Amagai M, Bruckner AL, Enk AH, Margolis DJ, McMichael AJ, et al., editors. Fitzpatrick's Dermatology. $9^{\text {th }}$ ed. New York: McGraw-Hill Education; 2019. p. 3107-34

2. Murtiastutik D. AIDS. Dalam: Barakbah J, Lumintang H, Martodihardjo S, editor. Buku ajar infeksi menular seksual. Surabaya: Airlangga University Press; 2018.

3. Haryati MR, Asmarawati TP, Hadi U. Informasi dasar HIV/AIDS. Dalam: Hidayati AN, Rosyid AN, Nugroho CW, Asmarawati TP, Ardhiansyah AO, Bakhtiar A et al., editor. Manajemen HIV/AIDS: terkini, komprehensif, dan multidisiplin. Surabaya: Airlangga University Press; 2019.

4. Kementerian Kesehatan Republik Indonesia. Infodatin HIV AIDS. Jakarta: Pusat Data dan Informasi Kementerian Kesehatan RI; 2020.

5. Azfar NA, Khan AR, Zia MA, Humayun A, Malik LM, Jahangir M. Frequency of mucocutaneous manifestations in HIV positive Pakistani patients. J Pak Assoc Dermatol 2011; 21(3): 149-53.

6. Botting RA, Rana H, Bertram KM, Rhodes JW, Baharlou H, Nasr N, et al. Langerhans cells and sexual transmission of HIV and HSV. Rev Med Virol 2016; 27(2): 1923.

7. Moustaide K, Nassiri A, BayBay H, Gallouj S, Rabhi S, Mernissi FZ. Profile of dermatological manifestations in seropositive patients correlated with CD4 count sample of a Moroccan population. Yumed Text 2019. 1(1): 1-6.

8. Sharma P, Agrawal M, Saxena A. A study of sexually transmitted infections among HIV infected patients in correlation with their CD4 T cell counts. Indian J Clin Exp Dermatology 2020; 6(3): 257-60.

9. Khat N, Kudligi C, Rathod RM, Kuntoji V. Original article: a clinical study of mucocutaneous manifestation of HIV / AIDs and its correlation with CD4 count. J Pak Assoc Dermatol 2020; 30(4): 550-7.

10. Pudjiati SR, Dewi NA, Palupi SSA. Correlation between CD4 cell counts with mucocutaneous manifestations: study of HIV patients in Dr.
Sardjito General Hospital, Yogyakarta. $\mathrm{J}$ thee Med Sci 2018; 50(1): 42-9.

11. Tahir K, Alam F, Hussain I, Ashraf S. Frequency of mucocutaneous manifestations in HIV positive patients. J Pak Assoc Dermatol 2018; 28(4): 4205.

12. Khondker L. Dermatological manifestations of HIV/AIDS patients. J Enam Med Coll 2018; 9(3): 185-8.

13. Muthanna A, Jamil A. Cutaneous infections among human immunodeficiency virus (HIV) infected patients in a single centre in Kuala Lumpur, Malaysia. Microbes Infect 2021; 1(1): 17.

14. Haridas N, Muhammed K, Sarita S. Mucocutaneous infections in HIV positive patients attending a tertiary care institution: a descriptive study. Int J Dermatol 2017; 1(4): 1-5

15. Rajput PS, Das AK, Paudel U, Parajuli S. Mucocutaneous disorders in HIV/AIDS at a tertiary care hospital in Nepal: An observational study. Our Dermatol Online 2021; 12(2): 101-5.

16. Abhinandan HB, Suresh KJ, Asha N, Ramesh K, Manali J, Jitendra B, et al. Cutaneous manifestations of HIV-infection in relation with CD4 cell counts in Hadoti region. J Evol Med Dent Sci 2013; 2(36): 6703-14.

17. Hidayati AN. Infeksi menular seksual pada HIV/AIDS: sifilis, herpes simpleks genitalis, dan kondiloma akuminata. Dalam: Hidayati AN, Rosyid AN, Nugroho CW, Asmarawati TP, Ardhiansyah AO, Bakhtiar A et al., editor. Manajemen HIV/AIDS: Terkini, Komprehensif, dan Multidisiplin. Surabaya: Airlangga University Press; 2019.

18. Lii YY, Yang SH, Wang RR, Tang JT, Wang HM, Kuang YQ. Effects of CD4 cell count and antiretroviral therapy on mucocutaneous manifestations among HIV/AIDS patients in Yunnan, China. Int J Dermatol 2019; 1(1): 1-6.

19. Alinda MD. Dermatosis noninfeksi pada HIV/AIDS. Dalam: Hidayati AN, Rosyid AN, Nugroho CW, Asmarawati TP, Ardhiansyah AO, Bakhtiar A et al., editor. Manajemen HIV/AIDS: Terkini, Komprehensif, dan Multidisiplin. Surabaya: Airlangga University Press; 2019.

20. Hidayati AN, Sari M. Keganasan oportunis kulit pada HIV/AIDS. Dalam: Hidayati AN, Rosyid AN, Nugroho CW, Asmarawati TP, Ardhiansyah AO, Bakhtiar A et al., editor. Manajemen HIV/AIDS: Terkini, Komprehensif, dan Multidisiplin. Surabaya: Airlangga University Press; 2019. 